\title{
The Politics of Violence Reduction: Making and Unmaking the Salvadorean Gang Truce
}

\author{
Chris van der Borgh ${ }^{1 \star}$ and Wim Savenije ${ }^{2}$ \\ ${ }^{1}$ Utrecht University and ${ }^{2}$ FLACSO Argentina/UCA El Salvador \\ ${ }^{*}$ Corresponding author. Email: c.vanderborgh@uu.nl
}

(First published online 23 August 2019)

\begin{abstract}
This paper analyses a government-facilitated truce, begun in 2012, between El Salvador's three principal street gangs. Using field theory and securitisation theory, it maps the evolution of the truce, distinguishing between the three related processes of making the deal, keeping the truce, and resisting it. It analyses the complex and intriguing political processes in which various actors, such as gang leaders, government officials and international organisations, interacted with each other and made deals about the use and visibility of violence and ways of diminishing, preventing or hiding it.
\end{abstract}

Keywords: gang truce; violence reduction; hybrid security governance; truce politics; strategic action field

\section{Introduction}

There are a large number of cities and regions around the world where armed criminal actors, in defiance of the law, have built up power positions and exert territorial control. The phenomenon is particularly acute in a number of Latin American countries, such as Colombia, Brazil and the Northern Triangle of Central America, but is also present in other countries, including Nigeria, South Africa and Pakistan. ${ }^{1}$ Government responses display marked differences in their capacity to dismantle or crack down on these groups, and to contain the violence they use. Indeed, repression can easily lead to extreme reactions, causing even more violence. This can make accommodation with armed non-state actors seem an attractive option. However, making deals with armed groups, or facilitating pacts between them, can strengthen the same groups. Furthermore, it is morally and politically difficult to defend negotiating with violent criminals. ${ }^{2}$ Although gang truces are a well-known kind of intervention to reduce

\footnotetext{
${ }^{1}$ Kees Koonings and Dirk Kruijt (eds.), Violence and Resilience in Latin American Cities (London: Zed Books, 2015); Adrienne LeBas, 'Violence and Urban Order in Nairobi, Kenya and Lagos, Nigeria', Studies in Comparative International Development, 48 (2013), pp. 240-62; Huma Yusuf, Conflict Dynamics in Karachi (Washington, DC: United States Institute of Peace, 2012).

${ }^{2} J o s e ́$ Miguel Cruz and Angélica Durán-Martínez, 'Hiding Violence to Deal with the State: Criminal Pacts in El Salvador and Medellin', Journal of Peace Research, 53: 2 (2016), pp. 197-210.

(C) Cambridge University Press 2019. This is an Open Access article, distributed under the terms of the Creative Commons Attribution licence (http://creativecommons.org/licenses/by/4.0/), which permits unrestricted re-use, distribution, and reproduction in any medium, provided the original work is properly cited.
} 
gang-related violence, empirical research evidence on them is still quite limited. ${ }^{3}$ This paper analyses a much-debated example of such a process, the Salvadorean gang truce, which was intended to reduce violence by actively involving the actors allegedly responsible for the violence that it sought to contain.

In March 2012 the news website El Faro reported that the three principal Salvadorean street gangs (Mara Salvatrucha and the two factions of Barrio 18) had signed a truce supported by the minister of justice and public security (JPS). ${ }^{4}$ The truce was brokered in Zacatecoluca high-security prison, and led to a marked reduction in El Salvador's extremely high homicide rate. The capacity to rein in the violence attributed to the gangs became the most important selling point of the actors (national and international) who were proposing to dialogue or work with gangs. However, the involvement of gangs in efforts to resolve the problems they caused was surrounded by debates and conflicts about the very idea of a truce, the terms that had been negotiated, the motivations of the parties to become involved, the proposed arrangements to make it work, and its preliminary results. Street gangs are generally not considered legitimate actors to talk to, and their capacity and willingness to work towards social or political solutions to the gang problem is questioned. ${ }^{5}$ The last word has not been spoken about the truce, which - after it unravelled over the course of 2013 - became the subject of a criminal investigation by the Salvadorean chief public prosecutor and led to the arrest, in May 2016, of some of the key figures who had facilitated the truce. ${ }^{6}$

This article aims to contribute to our understanding of what is a rather mysterious, unique and 'atypical' case of a government dealing with gangs and violence that has puzzled journalists, academics and even some of the key stakeholders directly involved in the process. We argue that the truce should be analysed not as a

\footnotetext{
${ }^{3}$ See ibid. for an interesting discussion on the conditions under which truces or criminal pacts lead to violence reduction (or its concealment), and of truces and pacts in Colombia and El Salvador. A report comparing gang truces in the United States and Trinidad and Tobago states that, while during a truce violence is reduced, after it is over violence usually reaches higher levels than before; but also that a truce may create new opportunities for conflict and solidify alliances between gangs. See E. R. Maguire, 'Research, Theory, and Speculation on Gang Truces', paper presented at the seminar 'What Happens when Governments Negotiate with Organized Crime? Cases [sic] Studies from the Americas', Woodrow Wilson International Center for Scholars, Washington, DC, 30 Oct. 2013, https://www.wilsoncenter.org/ sites/default/files/Maguire\%20-\%20US\%20and\%20Trinidad\%20-\%20Paper_0.pdf. All URLs were last accessed on 18 April 2019 unless otherwise noted.

${ }^{4}$ Efren Lemus and Carlos Martínez, 'Raúl Mijango hace público comunicado conjunto de la Mara Salvatrucha y el Barrio 18', https://elfaro.net/es/201203/noticias/8078/Ra\%C3\%BAl-Mijango-hace-p\%C3\% BAblico-comunicado-conjunto-de-la-Mara-Salvatrucha-y-el-Barrio-18.htm.

${ }^{5}$ Teresa Whitfield, 'Mediating Criminal Violence: Lessons from the Gang Truce in El Salvador', Oslo Forum Papers, Centre for Humanitarian Dialogue, Lausanne, 2013.

${ }^{6}$ Most of those arrested were released shortly thereafter and the case against them was initially thrown out by the presiding judge, who argued that political responsibility for the truce should rest with the then minister of JPS, David Munguía Payés. Nonetheless, to date the former JPS minister has not been formally charged. In March 2018, however, the Cámara Especializada de lo Penal (Specialist Criminal Court) ordered a retrial of those who had been acquitted in August 2017. See 'Juez exonera acusados por tregua y apunta a Munguía Payés', La Prensa Gráfica, 30 Aug. 2017, pp. 18-19; and 'Nuevo juicio por la tregua de pandillas', La Prensa Gráfica, 21 March 2018, pp. 4-6. By February 2018 fresh lawsuits had been filed against one of the facilitators of the truce, Raúl Mijango, who has been in custody since August 2017. See 'Mijango fue acusado de dos delitos en caso tregua', El Diario de Hoy, 7 May 2016, p. 30, and 'Suman acusación de homicidio a Raúl Mijango', La Prensa Gráfica, 16 Feb. 2018, p. 8.
} 
'one-off deal between gangs and the government, but as a series of political moves in the broader strategic action field of security governance (FSG). ${ }^{7}$ Our analysis focuses both on the measures taken by different actors which made the gang truce possible and on those taken by actors who, at a later stage, dismantled it. It also looks at the ways in which support (in favour of and against the truce) was garnered, secured and lost during the different phases of the truce process. In order to analyse and explain the dynamics of the processes in which security arrangements were made and unmade, a conceptual and explanatory framework is developed which is based on insights from the literature on hybrid security governance, securitisation theory and field theory. This framework can bring to light the complex, multi-layered, non-linear and significant unintended dynamics of 'truce politics' in the Salvadorean case. It is also relevant for other studies of the politics of security governance where non-state armed actors have built up positions of power and challenge the state's monopoly over it.

The paper is structured as follows. In the next section we outline the key concepts, the explanatory framework and our methodology used to analyse this case of truce politics. In subsequent sections, we discuss three related processes of truce politics: firstly, making the truce. This was largely a secretive process in that it was, at least initially, the work of a small group of people. When the deal became public, a number of new processes and dynamics - previously unplanned and unimagined - took shape, involving a wider and growing range of stakeholders. One of these processes will be discussed in the second section: the effort - by a coalition of national and international actors, such as NGOs, the Organization of American States (OAS), the European Union (EU), gang leaders, facilitators and government officials - to keep the truce. Thirdly, from the very start the truce was the subject of intense national public debate, in which the key topic was whether the measures to deal with gangs were legitimate, effective and morally valid. Indeed, the very question as to whether the truce contributed to security or to insecurity was at stake. We argue that over time passive political support gave way to growing opposition to the truce, which marked its unravelling. Finally, we draw some conclusions about the truce and truce politics, reflecting on the particular case study as well as on its wider significance. While our analysis provides concrete and context-dependent knowledge about a unique process which is important in its own right, we also indicate how the analytical framework developed in this paper is relevant to other cases of hybrid security governance. ${ }^{8}$

\section{Truce Politics}

What the truce actually entailed was contested from the moment that its existence was revealed. While facilitators of the truce argued that it was a sincere and unique opportunity to contain violence and make peace in El Salvador, others held that it was, rather, an effort to secure the interests of the key actors involved, such as those

\footnotetext{
${ }^{7}$ We use the term 'truce' here to refer to the agreement that was reached between the gangs and the process by which it was forged, kept and dissolved.

${ }^{8}$ Bent Flyvberg, 'Five Misunderstandings about Case-Study Research', in Qualitative Inquiry, 12: 2 (2006), pp. 219-45; Christian Lund, 'Of What is this a Case?: Analytical Movements in Qualitative Social Science Research', Human Organization, 73: 3 (2014), pp. 224-34.
} 
of criminal gangs. ${ }^{9}$ In his book Infiltrados, Héctor Silva argues that it provided a smokescreen to conceal the involvement in drug trafficking of high-level police officials and political elites, including the director of the Policía Nacional Civil (National Civil Police, PNC) and the minister of JPS. ${ }^{10}$ Even the very claim that violence had been reduced was contested, with José Miguel Cruz and Angélica Durán-Martínez arguing that violence was merely made less visible. ${ }^{11}$ Journalists' accounts and research papers have pointed to the complexity of the process and the divergent and changing understandings of it on the part of the different actors involved. ${ }^{12}$ We argue that the truce should be seen not simply as an initiative that was informed by one set of interests, but rather as a multifaceted political process in which new security policies were introduced, embraced and resisted. One of the most puzzling aspects of the truce was the fact that it came into existence in the first place, and that it survived for more than a year in a context where heavyhanded approaches to gangs were dominant and traditionally received high levels of popular support. ${ }^{13}$ In order to analyse the assemblage of smaller and larger political moves, practices and interactions carried out by a variety of actors and leading to the emergence and demise of the truce, we draw on studies of hybrid security governance, securitisation and strategic action fields. The notion of the strategic action field points to the existence of rules governing the interactions of actors, while acknowledging that these rules can always be challenged. ${ }^{14}$ Neil Fligstein and Doug McAdam predict that changing such rules will not be easy, since incumbents usually have strong vested interests in the status quo and are therefore determined to ward off any challenge to alter it. We see the truce as a series of (new) practices that fundamentally challenged the rules of the field of security governance. ${ }^{15}$ However, the rules of the game are not necessarily crystal clear, and they can vary over time and place. We argue that, in order to understand how the truce emerged and why it was deeply contested, we need to take into account the interplay between formal and informal practices on the one hand, and backstage and frontstage processes on the other. ${ }^{16}$

\footnotetext{
${ }^{9}$ Douglas Farah and Pamela Philips Lum, 'Central American Gangs and Transnational Criminal Organizations: The Changing Relationships in a Time of Turmoil' (2013), https://www.ibiconsultants. net/_pdf/central-american-gangs-and-transnational-criminal-organizations-update-for-publication.pdf.

${ }^{10}$ Héctor Silva, Infiltrados. Crónica de la corrupción en la PNC (1992-2013) (San Salvador: UCA Editores, 2013), pp. 211-13 and 264.

${ }^{11}$ Cruz and Durán-Martínez, 'Hiding Violence', p. 207.

${ }^{12}$ Whitfield, 'Mediating Criminal Violence'. The online journal El Faro has published extensively on the truce, and journalists working on this platform have also reflected on its longer-term process. See for instance Roberto Valencia, 'Obituario de la Tregua', El Faro, 13 April 2015, http://www.elfaro.net/es/ 201504/opinion/16835/Obituario-de-la-Tregua.htm.

${ }^{13}$ Chris van der Borgh and Wim Savenije, 'De-securitising and Re-securitising Gang Policies: The Funes Government and Gangs in El Salvador', Journal of Latin American Studies, 47: 1 (2015), pp. 149-76.

${ }^{14}$ Neil Fligstein and Doug McAdam, A Theory of Fields (Oxford: Oxford University Press, 2012).

${ }^{15}$ Thierry Balzacq, Tugba Basaran, Didier Bigo, Emmanuel-Pierre Guittet and Christian Olsson, 'Security Practices', in Robert A. Denemark (ed.), The International Studies Encyclopedia Online (Oxford: Blackwell Publishing, 2010), http://www.open.ac.uk/researchprojects/iccm/files/iccm/olsson-christian-publication7. pdf, last access 10 May 2019.

${ }^{16}$ Niagale Bagayoko, Eboe Hutchful and Robin Luckham, 'Hybrid Security Governance in Africa: Rethinking the Foundations of Security, Justice and Legitimate Public Authority', Conflict, Security and Development, 16: 1 (2016), pp. 1-32; Jan van Tatenhove, Jeannette Mak and Duncan Liefferink, 'The
} 
Following Pierre Bourdieu and Loïc Wacquant, we view society as an 'ensemble of relatively autonomous spheres of play that cannot be collapsed under an overall societal logic' and in which each field 'prescribes its particular values and possesses its own regulative principles' ${ }^{17}$ Fligstein and McAdam use the concept of strategic action fields (SAFs), or meso-level orders, as 'the main structural building block of modern/political life' ${ }^{18}$ In each SAF actors have a shared understanding of what is going on and what is at stake in the field. Actors in the field possess different degrees of power, while they have a common understanding of the rules - 'the patterns that people follow in social life ${ }^{19}$ - which provide an understanding of tactics that are possible and legitimate. ${ }^{20}$ However, the common-sense understanding of rules does not imply that actors have the same interpretative frames, since fields are 'only rarely truly organised around a "taken for granted" reality'. ${ }^{21}$ In each SAF, the embedded social actors seek to fashion and maintain order. Rather than looking at the interests and power of individual actors, Fligstein and McAdam emphasise the importance of social skill, the 'capacity of intersubjective thought and action that shapes the provision of meaning, interests, and identity in the service of collective ends'. ${ }^{22}$ Framing is an important social skill which points to 'action-oriented sets of beliefs and meanings that inspire and legitimate [...] activities and campaigns'. 23

The two important issues at stake in the security field are 'threat design' - the process whereby the security character of public problems is established - and 'threat management' - the fixing of the social commitments resulting from the collective acceptance that a phenomenon is a threat, and the possibility that a particular policy is created. ${ }^{24}$ Both are informed by the dominant rules in the SAF of security governance. In El Salvador, it is broadly accepted that gangs form a security threat, while the way the threat should be managed is open to discussion, with a majority favouring more repressive policies and some voices pleading for more collaborative approaches. ${ }^{25}$ The very fact that a truce was brokered reveals, in the words of Thierry Balzacq et al., that "security" cannot be considered as a concept

Inter-play between Formal and Informal Practices', Perspectives on European Politics and Society, 7: 1 (2006), pp. 8-24.

${ }^{17} \mathrm{~A}$ field is 'a patterned system of objective forces - much like a magnetic field, it is a field of conflict and competition as well': Pierre Bourdieu and Loïc Wacquant, An Invitation to Reflexive Sociology (Chicago, IL: University of Chicago Press, 1992), p. 17.

${ }^{18}$ Fligstein and McAdam, A Theory of Fields, p. 1.

${ }^{19}$ Ibid., p. 26.

${ }^{20}$ Rules as such are not necessarily 'known' as in games. Anthony Giddens argues that 'rules generate or are the medium of the production and reproduction of - practices': Anthony Giddens, Central Problems in Social Theory: Action, Structure and Contradiction in Social Analysis (Basingstoke: Macmillan, 1979), p. 67.

${ }^{21}$ Fligstein and McAdam, A Theory of Fields, p. 11.

${ }^{22}$ Ibid., p. 4.

${ }^{23}$ Robert D. Benford and David A. Snow, 'Framing Processes and Social Movements: An Overview and Assessment', Annual Review of Sociology, 26 (2000), p. 614.

${ }^{24}$ Thierry Balzacq, Sarah Léonard and Jan Ruzicka, “'Securitization” Revisited: Theory and Cases', International Relations, 30: 4 (2016), pp. 494-5.

${ }^{25}$ For a discussion about collaborative and conflictive approaches, see Eduardo Moncada, 'The Politics of Urban Violence: Challenges for Development in the Global South', Studies in Comparative International Development, 48: 3 (2013), pp. 217-39. 
which can capture a coherent set of practices' but rather as 'a kaleidoscope of practices non-reducible to a core meaning and/or a linguistic formulation' ${ }^{26}$ Indeed, it shows that the field of security governance is 'essentially contested'. ${ }^{27}$

As to the actors involved in the debates about threat management, several distinctions can be made. Fligstein and McAdam distinguish between incumbents and challengers in an $\mathrm{SAF}^{28}$ while in securitisation theory the relationships and interactions between 'securitising actor(s)' (who define threats to security), and audiences (whose consent the securitising actor seeks) are usually stressed. ${ }^{29}$ Neither distinction is unproblematic. As our analysis of the truce will show, the positions of actors can be blurred or fluid, with incumbents implicitly challenging the rules of the game, and support for challengers rapidly growing or fading. The concepts of and relationships between securitising actors and audiences have been hotly debated in the literature. ${ }^{30}$ We follow Balzacq, who emphasises the intersubjective nature of the process of securitisation in which there can be multiple audiences, and where the roles of the audience(s) and securitising actor can be blurred. ${ }^{31}$ Although some actors clearly have more power than others to define threats and to propose ways to manage them, the power to define threats and to legitimise practices of threat management is not a given and can be challenged and resisted by seemingly less powerful actors in the security field. In our analyses we therefore make a pragmatic distinction between (a) those actors introducing or blocking new security practices, and (b) the mobilisation and actions of actors in support of or against these practices.

Lastly, in the analysis of the truce the distinction between formal and informal rules and practices is of great importance. Over the past decade, growing attention has been paid to informal practices in security governance, as well as to the connections between formal and informal practices. ${ }^{32}$ Formal practices and rules are 'for the most part codified through publicly recognised rules, ${ }^{33}$ while informal practices are 'those non-codified settings of day-to-day interaction concerning policy issues, [...] not structured by pre-given sets of rules or formal institutions'. ${ }^{34}$ Formal

\footnotetext{
${ }^{26}$ Balzacq et al., 'Security Practices'.

${ }^{27}$ Fligstein and McAdam, A Theory of Fields, p. 12.

${ }^{28}$ Ibid, p. 13.

${ }^{29}$ Thierry Balzacq, 'A Theory of Securitization: Origins, Core Assumptions, and Variants', in Thierry Balzacq (ed.), Securitization Theory. How Security Problems Emerge and Dissolve (Abingdon and New York: Routledge, 2011), pp. 8-9.

${ }^{30}$ Adam Côté, 'Agents without Agency: Assessing the Role of the Audience in Securitization Theory', Security Dialogue, 47: 6 (2016), pp. 541-58; Rita Floyd, 'Extraordinary or Ordinary Emergency Measures: What, and Who, Defines the "Success" of Securitization?', Cambridge Review of International Affairs, 29: 2 (2016), pp. 677-94.

${ }^{31}$ Balzacq, 'A Theory of Securitization'.

${ }^{32}$ Bagayoko et al., 'Hybrid Security Governance'; Bruce Baker, 'Linking State and Non-State Security and Justice', Development Policy Review, 28 : 5 (2010), pp. 597-616; Robin Luckham and Tom Kirk, 'The Two Faces of Security in Hybrid Political Orders: A Framework for Analysis and Research', Stability: International Journal of Security and Development, 2: 2 (2013), http://doi.org/10.5334/sta.cf; Sonja Wolf, 'Formal and Informal Security Governance in the Americas', Latin American Research Review, 50: 3 (2015), pp. 275-85.

${ }^{33}$ Bagayoko et al., 'Hybrid Security Governance', p. 7. The authors are writing about informal and formal institutions.

${ }^{34}$ Van Tatenhove et al., 'The Inter-play between Formal and Informal Practices', pp. 14-15.
} 
practices will be easier to legitimise, but informal practices (e.g. illegal self-defence groups) can also be seen as legitimate, while there are cases of formal practices that are considered illegitimate (e.g. defence of rights of prisoners). Informal practices do not necessarily aim to circumvent or challenge existing rules, but can, for instance, also come into existence to 'grease the wheel' or to allow experimentation with other approaches. ${ }^{35}$ It is therefore important to take into account where and why these practices take place; informal practices that take place backstage can signal the circumvention of formal rules. It should be stressed, however, that informal and formal practices can merge in complex ways, leading to forms of hybrid security governance. In addition, as will become clear in the discussion of this case, practices can move from backstage to frontstage, while discussion about the actual status of these practices (are they formal or informal, legal or illegal?) is part and parcel of the contestations in the FSG.

The data used in this research were collected over several periods of fieldwork between 2012 and 2017. We scrutinised reports, academic publications and newspaper articles about the truce process, and during and after the truce period we interviewed key stakeholders who had been involved in the truce (facilitators, government officials, gang leaders), at both national and local level, as well as analysts, policy makers and academics. In identifying relevant interactions in the FSG, we make a distinction between different types of interaction in and between actors: the government, the gangs, churches, political parties, the mediators and the international support structures. We analyse the truce as an episode of contention, and Fligstein and McAdam's methodological considerations with regard to field analysis (in particular rupture/crisis/resettlement) have guided our analysis of the main processes and practices in (and around) the FSG explaining the emergence and unravelling of the truce. ${ }^{36}$

\section{The Background to the Salvadorean Truce}

The truce was a new way to deal with the gang phenomenon that had become one of the main security problems in El Salvador. While street gangs had existed for a long time, the number of gang members steadily increased after the end of the civil war in 1992, and the gangs' characteristics changed. The phenomenon was deeply influenced by the massive migration of Salvadoreans to the United States. Returning youngsters 'imported' US gang culture back into El Salvador, and the US policy of deporting immigrants with criminal records to their country of origin (adopted in 1992) led to a growing influx of gang members and influence from the US gang experience. ${ }^{37}$ In this period alleged gang members were actively targeted by the Los Angeles Police Department for deportation. ${ }^{38}$ These returning gang members brought Mara Salvatrucha and Barrio 18 to El Salvador and eventually

\footnotetext{
${ }^{35}$ Ibid., p. 15.

${ }^{36}$ Fligstein and McAdam, A Theory of Fields, pp. 167-8.

${ }^{37}$ Donna Decesare, 'The Children of War: Street Gangs in El Salvador', NACLA Report on the Americas, 32: 1 (1998), pp. 21-9.

${ }^{38}$ Elana Zilberg, 'Fools Banished from the Kingdom: Remapping Geographies of Gang Violence between the Americas (Los Angeles and San Salvador)', American Quarterly, 56: 3 (2004), pp. 759-79.
} 
most local Salvadorean gangs joined one of these gangs, while maintaining a substantial degree of autonomy.

Central American street gangs share many of the characteristics of US street gangs, but - emerging in a different socio-political context, and as a result of ineffective government policies to deal with gangs - the Central American ones have become far more violent and disruptive. ${ }^{39}$ Street gangs generally have a presence in marginalised neighbourhoods, villages and settlements, where they claim or pursue a kind of 'territorial control'. Control of territory primarily means that local residents' cooperation with the gang is expected or enforced, and that suspected outsiders are prevented from entering the neighbourhood. Depending on the strength of cliques, local residents need to adapt to the gangs' presence and their street code. ${ }^{40}$ Furthermore, shop keepers and bus drivers, and, increasingly, other local residents are obliged to pay extortion money (renta) to gangs. This is one of their main sources of income. Thus, Salvadorean street gangs have become influential non-state actors, with a capacity to use violence and to extract resources.

The number of gang members is hard to estimate. In 2013, sources close to the gangs estimated that there were 60,000 gang members in the neighbourhoods and approximately 10,000 in the penal system. These sources also conjectured that the gangs had a social support network of some 400,000 citizens including, for instance, family members and neighbours. ${ }^{41}$ With the proliferation of the gang phenomenon, many residents in marginalised neighbourhoods have connections with gang members, e.g. through family or neighbourhood ties. Furthermore, some non-gang youths are involved in practical tasks (the collection of extortion money and surveillance). With a large number of gang members imprisoned, prisons have become an integral part of gang structures, giving rise to a situation in which a prison-based national leadership - ranfla - 'wields considerable authority, and neighbourhood clicas retain a degree of autonomy regarding economic activity and relationships with other organisations'. ${ }^{4}$

Salvadorean government policies vis-à-vis gangs have changed over the past two decades. The general trend has moved from relative neglect in the 1990s to an emphasis on zero-tolerance approaches at the beginning of the millennium, to a certain recognition that more integrated approaches are needed. ${ }^{43} \mathrm{~A}$ common thread in the government responses to gangs, however, is a weak capacity to formulate and implement a coherent approach, and a continuing and recurring focus on

\footnotetext{
${ }^{39}$ José Miguel Cruz, 'Criminal Violence and Democratization in Central America: The Survival of the Violent State', Latin American Politics and Society, 53: 4 (2011), pp. 1-33; Wim Savenije, Maras y barras: Pandillas y violencia juvenil en los barrios marginales de Centroamérica (San Salvador: FLACSO El Salvador, 2009), p. 18.

${ }^{40}$ Wim Savenije and Chris van der Borgh, 'San Salvador: Violence and Resilience in Gangland', in Koonings and Kruijt (eds.), Violence and Resilience, pp. 90-108.

${ }^{41}$ Ana Glenda Tager and Isabel Aguilar Umaña, La tregua entre pandillas salvadoreñas: Hacia un proceso de construcción de paz social (Guatemala City: Interpeace, 2013), p. 5.

${ }^{42}$ Whitfield, 'Mediating Criminal Violence', p. 8.

${ }^{43}$ Oliver Jütersonke, Robert Muggah and Dennis Rodgers, 'Gangs, Urban Violence, and Security Interventions in Central America', Security Dialogue, 40: 4-5 (2009), pp. 373-97; Wim Savenije and Chris van der Borgh, 'Anti-gang Policies and Gang Responses in the Northern Triangle', The Broker, 3 July 2014, http://www.thebrokeronline.eu/Articles/Anti-gang-policies-and-gang-responses-in-theNorthern-Triangle.
} 
repression. The idea that the gang phenomenon required a more comprehensive approach was emphasised by the Centre-Left coalition government headed by President Carlos Mauricio Funes (2009-14). The Funes government tried to develop a more integrated gang policy in its first year, but in the face of soaring homicide rates and constant media criticism at its failure to deal with the problem, the emphasis soon shifted back to repressive policies which made it extremely difficult - if not impossible - to make prevention work. ${ }^{44}$ In a context of rising homicide rates, retired general David Munguía Payés was appointed minister of JPS on 22 November 2011. Until that moment he had been minister of defence; his appointment was generally seen as a clear sign of determination on the part of the Salvadorean government to take an even more repressive approach to the gang phenomenon and of the 'militarisation' of security policies. ${ }^{45}$

In March 2012, only four months after his appointment, however, it was revealed that his ministry had facilitated a truce between the two principal gangs (Mara Salvatrucha and Barrio 18). The people who had facilitated the truce were from outside the government: former guerrilla commander and former member of parliament for the Frente Farabundo Martí para la Liberación Nacional (Farabundo Martí National Liberation Front, FMLN) Raúl Mijango and Monsignor Fabio Colindres, bishop of the military ordinariate of El Salvador. The mediations occurred with the explicit support of Minister Munguía Payés. As will be discussed in the next section, President Funes' public backing was ambiguous, but his support was of key importance to the whole initiative. The endorsement of the process by some high-level officials and their willingness to take measures to support it created the space to enable the dialogue between gang leaders to continue.

\section{Making the Truce}

Indeed, the (new) minister of JPS actively supported the initiative and was backed, at least initially, by the president. ${ }^{46}$ However, while high-level political support was a major factor, arriving at a truce required a great deal of strategic manoeuvring. That strategy consisted of a combination of frontstage politics that emphasised continued repression against gangs, which was communicated to the public at large, and backstage politics that were secretive and pragmatic. The backstage process entailed a novel set of security practices to reduce homicide rates by facilitating talks between gang leaders and encouraging a truce between the gangs. The combination of

\footnotetext{
${ }^{44}$ Jeannette Aguilar et al., La situación de la seguridad y la justicia 2009-2014. Entre expectativas de cambio, mano dura militar y treguas pandilleras (San Salvador: Instituto Universitario de Opinión Pública, 2014); van der Borgh and Savenije, 'De-securitising and Re-securitising Gang Policies'.

${ }^{45}$ Edgardo Amaya Cóbar, 'Militarización de la seguridad pública en El Salvador, 1992-2012', URVIO. Revista Latinoamericana de Seguridad Ciudadana, 12 (2012), pp. 71-82.

${ }^{46}$ The relation between Munguía Payés and President Funes dated back to the electoral campaign of 2008, when Funes made an alliance with Munguía Payés and the military group around him in order to neutralise the historical relationship between the Alianza Republicana Nacionalista (Nationalist Republican Alliance, ARENA) and the military and to enable a peaceful transition after two decades of ARENA rule. When Funes won the elections, this group's influence grew, and their role in politics and in security governance increased. See Ralph Sprenkels, 'La guerra como controversia: Una reflexión sobre las secuelas políticas del informe de la Comisión de la Verdad para El Salvador', Identidades, 2: 4 (2012), pp. 68-89.
} 
frontstage and backstage politics sought to reconcile the 'irreconcilable'. While repressive policies on the frontstage received high levels of popular approval, they had not led to a substantive drop in homicide rates in the past, but, rather, the opposite. This was problematic since the minister had promised to bring down homicide rates by at least 30 per cent; ${ }^{47}$ yet in the first months of Munguía Payés tenure as minister of JPS the number of homicides continued to increase substantially. ${ }^{48}$ In order to reduce homicide rates, he turned to the idea of dialogue with gangs. Since this was a sensitive topic in the public realm, it was safer to do so 'backstage'.

It is important to emphasise that some of these backstage practices were already in existence. Long before the Funes government took office, political parties had had talks with and made promises to gang members, for example during electoral campaigns. ${ }^{49}$ Even the idea of the involvement of the government in dialogues with gangs was not new. When the Funes administration took office in 2009, there were already some preliminary informal contacts in place between gangs and government representatives. ${ }^{50}$ Minister Munguía Payés repeatedly discussed the possibility of negotiations with gangs with Mijango, a former guerrilla commander and friend who worked with him when he was minister of defence. Mijango declared that 'David [Munguía Payés] was very clear about the fact that we would not resolve this phenomenon by repressive means. The possibility [of talking with gang leaders] presented itself when he became minister. ${ }^{51}$ However, while ad hoc contacts between gang leaders and politicians and government officials already existed, previous ministers had been extremely wary of dialoguing or negotiating with gangs. Minister Munguía Payés' move to actively support a truce was a break with that practice, and implied a profound change in the dominant rules of the FSG.

Thanks to high-level support from within the government, facilitators Mijango and Colindres had virtually unlimited access to the high-security prison in Zacatecoluca, where many of the more influential, or 'historical', leaders of the gangs were held. The then national director of the prison system, Nelson Rauda, allowed the facilitators to enter the prison and to have meetings with gang leaders. The details of the talks they had with the gang leaders and the final agreement they made are largely unknown, but the process made relatively fast progress and led to a deal between the gangs and some concessions by the government. ${ }^{52}$ While there are

\footnotetext{
${ }^{47}$ 'Munguía Payés declara la guerra al crimen’, Diario CoLatino, 29 Nov. 2011, p. 4.

${ }^{48}$ Roberto Valencia, 'El promedio de Munguía Payés supera en 1.4 homicidios diarios al de Melgar', $E l$ Faro, 27 Feb. 2012, https://elfaro.net/es/201202/noticias/7689/El-promedio-de-Mungu\%C3\%ADa-Pay\% C3\%A9s-supera-en-14-homicidios-diarios-al-de-Melgar.htm.

${ }^{49}$ High-level ARENA politicians had also talked to gangs, and even admitted that this was inevitable. Gabriel Labrador and Carlos Martínez, 'Ernesto Muyshondt: "Si querés ser político en este país tenés que tratar con ellos"', El Faro, 12 March 2016, http://www.elfaro.net/es/201603/el_salvador/18214/ Ernesto-Muyshondt-Si-querés-ser-político-en-este-país-tenés-que-tratar-con-ellos.htm.

${ }^{50}$ Van der Borgh and Savenije, 'De-securitising and Re-securitising Gang Policies', p. 163. According to Steven Dudley, Catholic priest Father Antonio (Toño) Rodríguez served as a facilitator in this attempt to open a dialogue: Steven Dudley, 'The El Salvador Gang Truce and the Church: What Was the Role of the Catholic Church?', CLALS Working Papers, 5 May 2013, https://ssrn.com/abstract=2412730.

${ }^{51}$ Carlos Martínez and José Luis Sanz, 'La nueva verdad sobre la Tregua entre pandillas', El Faro, 11 Sept. 2012, http://www.salanegra.elfaro.net/es/201209/cronicas/9612/La-nueva-verdad-sobre-la-Tregua-entrepandillas.htm.

${ }^{52}$ Ibid.
} 
no documents available relating to the actual truce and the different responsibilities of the parties involved, essentially it comprised promises by the imprisoned gang leaders to reduce violence and to cease attacks on the police and the armed forces. ${ }^{53}$ The government undertook to take the army out of the prisons, to improve conditions in penal institutions and to send some of the historical gang leadership to ordinary prisons, where they would be able to communicate the truce to other gang leaders, and convince them to implement and impose it on rank and file members. ${ }^{54}$ Importantly, when the truce got under way the government continued to provide the facilitators access to the imprisoned gang leaders to assist them in its coordination and implementation. Of the promises made by the gangs, the one to reduce violence was by far the most important and effective. The truce was followed immediately by a sharp drop in homicides, from almost 14 a day to five. ${ }^{55}$ The overall rate dropped by 41 per cent over 2012 , to 41.2 per 100,000 inhabitants. $^{56}$

The question why the minister of JPS and the historical leaders were interested in a deal has been the subject of speculation. Our interviewees pointed to Minister Munguía Payés' ambition to be a presidential candidate in the 2014 elections and that a reduction in homicide rates might bolster his popularity. A further reason is, as mentioned earlier, provided by Silva's argument that the truce provided a smoke screen to hide links between high-level police and government officials and organised crime. ${ }^{57}$ As to the interest of gang leaders, Douglas Farah and Pamela Philips Lum argue that their interest was merely a tactical move that has to be understood in relation to their alleged (and growing) involvement in organised crime activities. $^{58}$ In addition, there are persistent rumours that gang leaders received some form of financial compensation from the government. ${ }^{59}$ Paolo

\footnotetext{
${ }^{53}$ Whitfield, 'Mediating Criminal Violence', p. 13. Whitfield also mentions that it was agreed that bus drivers would no longer be subject to extortion. However, extortion was a topic that proved hard to address during the truce.

${ }^{54}$ Ibid., p. 11. Additional measures that were allegedly agreed were a relaxation in the prison regime and in conditions for visits and regarding the admittance of food, clothing and electronic equipment. See Valencia, 'Obituario de la Tregua'.

${ }^{55}$ 'Los homicidios bajan en marzo: PNC', La Prensa Gráfica, 31 March 2012, pp. 6-8; 'Abril cierra con promedio de cinco homicidios por día', La Prensa Gráfica, 1 May 2012, pp. 16-17; 'Homicidios bajan 30\% entre enero y julio 2012', La Prensa Gráfica, 31 July 2012, p. 25.

${ }^{56}$ These data are from the United Nations Office on Drugs and Crime (UNODC). The rate dropped from 69.9 homicides per 100,000 in 2011: UNODC, Global Study on Homicide. Trends/Contexts/Data 2013 (Vienna: UNODC, 2014). It has been argued that the reduction in homicide rates was replaced by an increase in the number of disappearances. See Douglas Farah, 'Central American Gangs are More Dangerous than Ever', InSight Crime, 27 Jan. 2016, http://www.insightcrime.org/news-analysis/centralamerica-gangs-are-more-dangerous-than-ever. For a critique of Farah's argument see Juan Martínez d'Aubuisson, 'International Terror and the Gangs of Douglas Farah', InSight Crime, 26 Feb. 2016, http:// www.insightcrime.org/news-analysis/international-terror-douglas-farah-gangs-ms13-barrio18. In many places extortion remained a common practice, although gangs were said to be behaving less aggressively and were more open to negotiating the amounts extorted (CvdB fieldwork notes, Feb. 2015).

${ }^{57}$ Silva, Infiltrados, p. 264.

${ }^{58}$ Farah and Philips Lum, 'Central American Gangs'.

${ }^{59}$ Héctor Silva Ávalos and Bryan Avelar, 'Case against El Salvador's M13 Reveals State Role in Gang's Growth', InSight Crime, 3 Aug. 2016, http://www.insightcrime.org/news-analysis/case-against-el-salvadors-ms13-reveals-state-role-in-gang-s-growth.
} 
Lüers, columnist for the influential national newspaper El Diario de Hoy and former member of the FMLN who became involved in the truce process in March 2012 and who had several meetings with various gang leaders in prison, argued that they had a genuine interest in a peace process, and that many years in prison had led to reflection on their part: 'I really had to review my ideas about the phenomenon [...] I was surprised by their knowledge, how they talked about war and peace, how they talked about Colombia [...] They were looking for a way out. ${ }^{60} \mathrm{We}$ argue that in the early stages of the truce the reasons which motivated the (still limited number of) stakeholders to become involved may have been relatively straightforward. For the government the truce in the early phase was primarily a pragmatic deal to control the escalating homicide rates, without an explicit security strategy. For the historical gang leaders, especially those in the high-security prisons, the truce promised better prison conditions and renewed influence over the gangs.

The essence of the deal was thus relatively straightforward: the imprisoned gang leadership promised to reduce the number of homicides committed by their 'homeboys ${ }^{61}$ on the streets. This could be achieved only by moving the historical leaders to ordinary prisons, which enabled close coordination with other imprisoned homeboys and a more fluid communication with cliques in the neighbourhoods, bolstering the leaders' ability to control their 'homies'; it was therefore key to making the truce work. It led to a strengthening of the historical leadership and to more hierarchical and effective relationships between this leadership and gang members on the streets. ${ }^{62}$ This was important because gang structures are complex networks that do not have a unified leadership. Raúl Mijango recalled that for gangs to reach internal agreements they had to seek the agreement of approximately 90 persons. The reason behind the facilitators' intention to strengthen the (imprisoned) historical leadership was, as Mijango said, that 'they best understood the peace process, were most committed and would be best able to promote it internally'. ${ }^{63}$ In this regard it is also telling that there was no (written) agreement about the exact implementation of or follow-up to the agreement. How would gang leaders communicate with their homies outside of the prisons? How would they exert control? What would happen if homeboys on the streets did not accept the terms of the truce? All this was left to the gang leaders themselves.

Minister Munguía Payés played a key role in creating the political space for the truce. Reliance on the capacity of the gang leadership to implement a truce and to control gang members from inside the prisons, in ways the leaders deemed appropriate, was a major innovation and a hybridisation of the rules in the FSG: government officials outsourced a part of the responsibility to contain the violence of street gangs to the gangs themselves. This implied a move towards a set of informal practices complementing formal government policy. Indeed, informal and formal practices merged in a way that, according to Niagale Bagayoko et al., is characteristic of hybrid governance arrangements. ${ }^{64}$ The rules of this new arrangement were

\footnotetext{
${ }^{60} \mathrm{CvdB}$ interview with Paolo Lüers, 18 April 2016, San Salvador.

${ }^{61}$ The terms 'gang members', 'homies' and 'homeboys' are used interchangeably in this article to refer to fellow members of the same gang.

${ }^{62}$ Savenije and van der Borgh, 'Anti-gang Policies and Gang Responses'.

${ }^{63}$ CvdB interview with Raúl Mijango, 9 Feb. 2015, San Salvador.

${ }^{64}$ Bagayoko et al., 'Hybrid Security Governance', p. 6.
} 
largely informal and implicit. The minister and the facilitators clearly did not want to become involved in the question of how the leadership would implement the truce or impose it on rank-and-file gang members. The basis for the window of opportunity for the truce to occur was this mutual, implicit and hidden recognition that the 'partners' (the government and the gangs) needed each other. Moreover, the deal was made - and arguably could only be made - 'backstage', out of sight of other relevant actors of the FSG (including government actors, such as the police and the judicial sector) and audiences (like the media) that would probably question the initiative. In this regard, while in El Salvador the truce was a unique effort to deal with gangs, it is not unlikely that controversial approaches that promise fast results in diminishing or containing high levels of violence can also be found in other countries in Latin America and beyond. However, what sets the case of El Salvador apart is that the early backstage phase of the gang truce (state and nonstate dealing with each other, and making deals about violence reduction), which was meant to be and remained hidden, moved frontstage.

\section{Keeping the Truce}

When, a few days after the start of the truce, El Faro reported that negotiations between the government and gangs to reduce homicide rates had taken place, ${ }^{65}$ the truce moved frontstage, which had several implications. First and foremost, the truce became the subject of intensive public debate involving a broad range of actors who discussed its legality, legitimacy and effectiveness. It was clear to most actors that the truce challenged existing practices of security governance, and that the very rules of the field itself were at stake. Secondly, the practices in support of the truce needed not only to be institutionalised, but also to be explained to the public at large. The key stakeholders (the gangs and the government) defended the deal principally by pointing out its effectiveness. In addition, a new platform emerged, uniting a range of national and international actors, that propagated the transformation of the truce into a more substantive and sustainable process. This section takes a closer look at these efforts to defend, keep and expand the truce.

When the public was informed about the truce, the government had to come up with a response. Initially representatives of the Salvadorean government denied the truce's existence, but in September 2012 Minister Munguía Payés claimed that he and the president were fully responsible. ${ }^{66}$ In the process of defending the initiative and responding to criticism of the truce, a pro-truce frame emerged that emphasised its effectiveness in drastically reducing the number of homicides. This frame was frequently used by the facilitators, who were active in the public debate about the truce. In the words of Raúl Mijango: 'We consider this the most effective action to prevent violence in the history of Latin America. [...] This process saved over 4,000 lives. ${ }^{67}$ However, Mijango and the gang leaders also sought to legitimise the reason for gangs to be involved in these efforts. While Mijango never ignored

\footnotetext{
${ }^{65}$ Martínez and Sanz, 'La nueva verdad sobre la Tregua entre pandillas'.

${ }^{66}$ Ibid.

${ }^{67}$ WS and CvdB interview with Raúl Mijango, 12 Feb. 2014, San Salvador.
} 
the crimes committed by many gang members, he argued that they were a product of their situation and both 'victims' and 'victimisers' ${ }^{68}$ In his language there was usually a conciliatory and forward-looking tone. He emphasised that gang members were 'the problem, but in their hearts they also have something good [...] we will convert the problem into a solution [...] This utopia is possible. ${ }^{69}$ In their declarations to the public, the gang leadership went beyond the argument of violence reduction and talked about peace and their willingness to be part of a broader solution. ${ }^{70}$ Leaders also claimed that instead of viewing gangs as a 'delinquent phenomenon', they should be seen as a 'social phenomenon'. ${ }^{71}$ 'It is necessary for you to understand that $[\ldots]$ the war that we have had to wage has socio-economic causes and therefore the solution is not simply about repression and legal measures, but also about social and economic measures. ${ }^{, 72}$

However, it is important to note that there was no unified stance within the gangs about the truce and that the pro-truce frame was used mainly by the historical leaders who had become more visible and who seemed to be open to change. But while these leaders were able to produce a more or less coherent discourse in their public declarations, at the neighbourhood level it was difficult to explain to local gang members what was going on and where they were going. ${ }^{73}$ In part, some members outside of prison perceived that the leaders in prison had benefitted most from the truce. ${ }^{74}$ But there was also an underlying issue: the very notion of what it meant to be a gang member. Status and respect within the gang had always been based on a record of being cool, tough and violent. In an interview, nonimprisoned leaders of the main gangs admitted to the difficulties of the truce for younger members who yearned for status and respect. One said: 'The gang is an identity. The problem is the illegal part of it. We want to reduce violence, and why not admit it - to make sure that our structures become productive in whatever sphere, education, healthcare, the environment. ${ }^{75}$ The construction of a new kind of gang identity, however, was not something young aspiring gang members would easily accept. ${ }^{76}$ Thus, the truce caused tensions within gangs themselves; it not only shifted power to imprisoned historical leaderships, but also intended or purported to change the basic rules governing the use of (gang) violence.

It is fair to say that the 'effectiveness frame' that stressed the reduction of homicide rates had much more resonance than the 'peace frame' that portrayed gangs as legitimate stakeholders in solving the problems they were (at least partly) responsible for.

\footnotetext{
${ }^{68}$ Mijango, cited by Whitfield, 'Mediating Criminal Violence', p. 10.

${ }^{69}$ WS and CvdB interview with Raúl Mijango, 12 Feb. 2014, San Salvador.

${ }^{70}$ For an overview of 13 declarations by gangs made public between 19 March 2012 and 18 May 2013, see Raúl Mijango, Tregua entre pandillas y/o proceso de paz en El Salvador (San Salvador: Red Imprenta, 2013), pp. 43-79. The emphasis that gang leaders placed on 'peace' as the main objective of the truce can be seen in their use of phrases such as 'contribuir a pacificación de El Salvador' (declaration of 2 May 2012) and 'la recuperación de la paz social' (declaration of 8 May 2013).

${ }^{71}$ See the declaration of 19 March 2012 in ibid., pp. 43-7.

${ }^{72} \mathrm{Ibid}$.

${ }^{73} \mathrm{CvdB}$ fieldwork notes, El Salvador, Feb. 2015.

${ }^{74} \mathrm{WS}$ and CvdB interviews with government officials involved in the truce process, 11-14 Feb. 2014, San Salvador.

${ }^{75} \mathrm{WS}$ and CvdB interview with gang members, 12 Feb. 2014, San Salvador.

${ }^{76} \mathrm{CvdB}$ interview with Raúl Mijango, 9 Feb. 2015, San Salvador.
} 
Indeed, the fact that violence reduction was the result of a deal between the gangs and the government remained contentious for many. Importantly, political party leaders supported the pro-truce frame that placed emphasis on the success of the truce in diminishing homicide rates. Mayors from the two main political parties qualified the truce process as an issue of general interest that should be placed above party politics. Supported by the party leadership, these mayors backed the facilitators' plans for a 'second phase of the truce' which was intended to promote processes of violence reduction and development at the local level. ${ }^{77}$ Jorge Velado, ARENA's vice-president in charge of policy, stated in an interview with El Faro that his party supported the initiative since it was reducing crime and homicide in the country. ${ }^{78}$ Furthermore, the then presidential candidate of the FMLN, Salvador Sánchez Cerén, stated on 2 May 2013 that he would support the truce and was even considering broadening the process to include new components, such as improving the prison infrastructure, the judicial system and crime prevention, and increasing access to the labour market and education. ${ }^{79}$ However, as would soon become clear, political support for the truce was largely pragmatic and based on the fact that it 'seemed to work'. At no point did a frame come into existence that resembled a broader consensus among the different stakeholders. The de facto changes of the rules in the FSG - giving gangs a role in violence reduction - were never really accepted.

Since the truce had been very much an 'ad hoc' move to reduce homicide rates, about which only few government officials had been informed, and since there were no concrete plans about whether and how to follow up on it, it enjoyed only limited political support within the government. There was no 'plan B', and the development of a government strategy in support of the truce proceeded slowly and proved to be extremely complex. Paolo Lüers emphasised the president's passive support for the truce and his (political) unwillingness to take further actions in its support. 'The minister of JPS did everything he could to try to convince the security cabinet to take further action, but nobody listened. Funes gave him free rein to reduce homicide rates, but he did not support further action. ${ }^{80}$ Thus, while high-level political 'support' was key in enabling the truce to take place, the lack of a plan, political ambiguity and lack of policy coherence explain why it was unable to go beyond the objective of violence reduction. ${ }^{81}$

Activities 'to keep the truce alive' were largely the result of continuing efforts by Raúl Mijango and Fabio Colindres and the capacity of the imprisoned gang leaders to impose it. Mijango maintained his contact with them, visiting them in prison on

\footnotetext{
${ }^{77}$ Mauro Arias, 'FMLN y Arena abrazan la tregua', El Faro, 18 Jan. 2013, https://elfaro.net/es/201301/ noticias/10771/FMLN-y-Arena-abrazan-la-tregua.htm.

${ }^{78}$ Carlos Martínez, 'No podemos dejar de abrazar una iniciativa que disminuye los crímenes', El Faro, 18 Jan. 2013, https://elfaro.net/es/201301/noticias/10770/\%E2\%80\%9CNo-podemos-dejar-de-abrazar-una-iniciativa-que-disminuye-los-cr\%C3\%ADmenes\%E2\%80\%9D.htm.

${ }^{79}$ 'Sánchez Cerén mantendrá tregua', La Prensa Gráfica, 3 May 2013, p. 22.

${ }^{80} \mathrm{CvdB}$ interview with Paolo Lüers, 18 April 2016, San Salvador.

${ }^{81}$ Douglas Moreno, vice minister of JPS and former national director of the prison system, blamed the government's lack of initiative and involvement in the truce process for his resignation in June 2013. See Carlos Martínez and José Luis Sanz, 'El ministro Perdomo se queda solo al frente de la tregua', El Faro, 6 June 2013, http://www.elfaro.net/es/201306/noticias/12295/El-ministro-Perdomo-se-queda-solo-al-frentede-la-tregua.htm.
} 
a regular basis to discuss the progress of the truce. With their consent and in close coordination with them, he devised a programme supporting the maintenance of the truce and the reduction of violence at the local level. Mijango was assisted by a staff of approximately 25 persons consisting of local leaders and gang representatives outside the prison. This staff helped to resolve the conflicts and tensions that threatened the truce within and between gangs throughout the territory of El Salvador. ${ }^{82}$ However, while the efforts to maintain the truce were essentially the business of the gangs, supported by the facilitators, broader support of government officials for these new security practices was crucial. Mijango and Colindres' access to the prisons would have been impossible without government consent. Moreover, the relative acceptance of the results of the truce by key political actors made it possible for government officials to use these unconventional means without having to pay a political price for them.

Another factor that provided support for the truce was the emergence of a new pro-truce platform some seven months after it started. Its organisational infrastructure consisted of non-state actors, in particular the two facilitators - who maintained contacts with gang leaders inside and outside of the prisons - the Organization of American States (OAS) and a newly established NGO called the Fundación Humanitaria (Humanitarian Foundation, FH). These actors formed a technical committee in support of the truce in which Munguía Payés also played a part. ${ }^{83}$ In particular, the involvement of the OAS was important, since it provided the truce with international backing, which was endorsed by the Salvadorean president. The OAS was keen to support the Salvadorean truce, believing that was a viable tool for dealing with soaring violence in other Latin American countries. ${ }^{84}$ The support of the OAS was also of symbolic importance, since the United States had declared itself squarely against the truce. ${ }^{85}$ In October 2012 the US Department of the Treasury declared Mara Salvatrucha to be a transnational criminal organisation. ${ }^{86}$ The US Agency for International Development (USAID) also made it clear that its funds should not be used for activities related to the truce. ${ }^{87}$

The creation of the FH itself was the outcome of a meeting organised in April 2012 at the initiative of the papal nuncio in El Salvador, Luigi Pezzuto. ${ }^{88} \mathrm{He}$ made clear to the attendees - including a number of Salvadorean bishops and some well-known figures from Salvadorean society - that the truce had to be supported and that this was the stance of the pope in Rome. ${ }^{89}$ He thus intervened in the

\footnotetext{
${ }^{82}$ WS and CvdB interview with Raúl Mijango, 14 Feb. 2014, San Salvador.

${ }^{83} \mathrm{See}$, for the terms of reference of this committee, Mijango, Tregua entre pandillas, pp. 102-13. See also OAS, 'OAS and El Salvador Agree to Establish a Technical Committee of Security Assistance to Strengthen the Peace Process between Gangs', 8 April 2013, http://www.oas.org/en/media_center/press_release.asp? sCodigo $=\mathrm{E}-128 / 13$.

${ }^{84}$ OAS, 'Report of the Secretariat of Multidimensional Security to the Committee on Hemispheric Security', OEA/Ser.G, CP/CSH-1484/13 (19 March 2013), http://scm.oas.org/IDMS/Redirectpage.aspx? class $=\mathrm{CP} / \mathrm{CSH} / \mathrm{SA}$ \& classNum $=199$ \&lang $=\mathrm{e}$.

${ }^{85}$ 'Designación de EUA reitera falta de apoyo a tregua de pandillas', La Prensa Gráfica, 6 March 2013.

${ }^{86}$ US Department of the Treasury, Press Release, 'Treasury Sanctions Latin American Criminal Organization', 11 Oct. 2012, https://www.treasury.gov/press-center/press-releases/Pages/tg1733.aspx.

${ }^{87}$ Designación de EUA reitera falta de apoyo a tregua de pandillas'.

${ }^{88} \mathrm{CvdB}$ interview with Paolo Lüers, 18 April 2016, San Salvador.

${ }^{89} \mathrm{Ibid}$.
} 
Catholic Church's debates about the truce, weakening the Salvadorean bishops' critical position, and providing substantial support to Bishop Colindres. ${ }^{90}$ The main goal of the FH was to support the truce, and to help move it forwards by involving civil society and mobilising financial support. Interestingly, the FH was founded by Salvadoreans who had previously not shown any interest in dealing with the gang problem. One of the founders was the former president of the Fundación Salvadoreña para el Desarrollo Económico y Social (Salvadorean Foundation for Economic and Social Development, FUSADES), a right-wing think tank. ${ }^{91}$ On 31 May 2013, in the presence of the facilitators and a number of ambassadors, the $\mathrm{FH}$ opened an office in the well-to-do neighbourhood of San Benito. ${ }^{92}$ International support for the process was broadened, as on this occasion the $\mathrm{EU}$ representative announced project funding for the $\mathrm{FH}$ as well as other initiatives in support of the truce. ${ }^{93}$ It has to be kept in mind, however, that although the FH was an initiative by civil society actors, it was not representative of Salvadorean society at large and seemed to represent a minority view. ${ }^{94}$

So, as the truce moved frontstage, a small group, led by the facilitators, kept it alive and looked for opportunities to expand it. Although the group was quite small, it counted on the support of influential national and international actors, including the OAS, the EU, the Salvadorean government and a small, but prominent, part of the Catholic Church hierarchy. However, as will become clear in the next section, it proved impossible to consolidate this support.

\section{Unmaking the Truce}

More than a year after its signing, the truce was still alive. While homicide rates had slightly increased, they were still relatively low. Efforts to build on the truce and transform it into a process that went beyond the pact between gangs had been flawed, but, by April 2013, it seemed to be entering a new phase. The facilitators and the gang leaders aimed to bring the process to selected municipalities initially called 'sanctuary-municipalities' and later 'municipalities free from violence'; ${ }^{95}$ this was also supposed to bring benefits to local communities and homies and their families. ${ }^{96}$

\footnotetext{
${ }^{90}$ Ibid.

${ }^{91}$ 'Fundación buscará fondos para sostener tregua entre pandillas', elsalvador.com, 22 Jan 2013, https://www. elsalvador.com/noticias/nacional/99521/fundacion-buscara-fondos-para-sostener-tregua-entre-pandillas/.

${ }^{92}$ Tager and Aguilar Umaña, La tregua. Cooperation between the facilitators and the FH was close: Raúl Mijango became the director of one of the FH's programmes.

${ }^{93} \mathrm{~A}$ representative of the $\mathrm{EU}$ present during the inauguration stated that the EU had examined the truce before deciding to provide financial support. See Tager and Aguilar Umaña, La tregua. For details about the EU funding see Delegación Europea en El Salvador, 'La Unión Europea destina 1.3 millones de euros para Plan Nacional "El Salvador seguro y en paz", 30 May 2013, http://eeas.europa.eu/delegations/el_salvador/ press_corner/all_news/news/2013/20130530_es.htm.

${ }^{94} \mathrm{~A}$ number of evangelical pastors also lent their support and launched their own initiative: 'Iniciativa pastoral ecuménica en El Salvador para apoyar la tregua entre las maras', InfoCatólica, 18 Nov. 2012, http://infocatolica.com/?t=noticia\&cod=13250.

${ }^{95}$ Diana Escalante, 'Las pandillas quieren municipios santuarios', El Diario de Hoy, 12 Dec. 2012, p. 22.

${ }^{96}$ This article focuses on the national initiative, not on its local dynamics. The idea of taking a local approach was certainly not new and had figured prominently in the preventive policies of NGOs and international organisations working in El Salvador. Furthermore, during the 2009 electoral campaign the FMLN
} 
However, this process would soon run aground in the face of increasing opposition at the national level. Within a very short period of time, the frames in support of the truce were increasingly attacked, passive support waned, and the capacity of the group led by the facilitators referred to above to 'keep the truce' was broken. Indeed, there had been a great deal of opposition to the truce. A large part of the population did not support it, preferring a repressive approach, arguing that the state should not negotiate with criminals, and suspecting that the gangs were not sincere in their commitments. As mentioned, the United States had declared itself against it, and also within the gangs the truce had met resistance. While this opposition may have fed into the dismantling of the truce, we argue that rapid changes in the dominant frames of key actors - the Church, the judiciary, political parties, a new minister of JPS - were crucial in the process. In early May 2013 political support for the truce was still being openly expressed by representatives of the major political parties. Just a couple of months later, by the end of June, those same politicians had distanced themselves from the truce. It had become an important topic in the campaign for the presidential elections of February 2014 and was increasingly presented as a threat and as a way of making common cause with criminals. However, it was not only the politicians who started to question the pro-truce frame. Other actors voiced their increasing opposition. This opposition was quickly adopted by political leaders and replaced the support that they had expressed just weeks earlier.

One of the first influential critiques of the truce came from Chief Public Prosecutor (in Spanish, 'Fiscal General') Luis Martínez, appointed on 4 December 2012. He had been critical about the truce process from the beginning, but on 17 April 2013 he attacked the truce in a televised interview, calling it a 'false and hypocritical negotiation' and asserting that the gangs involved were still carrying out extortions and assassinations. ${ }^{97}$ He reiterated this the next day and repeatedly thereafter. ${ }^{98}$ However, much more influential was criticism by the Conferencia Episcopal de El Salvador (CEDES). On 12 May 2013, CEDES published a communique in which the role played by Colindres - one of the facilitators of the truce - was criticised, stating that the truce had not produced the expected results and categorising the indiscriminate threats and violence by the gangs as terrorism. ${ }^{99}$ The declaration implied a radical break with the position of the (now former) nuncio of the Catholic Church, Pezzuto, who - as described above had called for the formation of a structure in support of the truce, thereby silencing the critical voices in CEDES.

This strong statement by CEDES provided Norman Quijano, presidential candidate for ARENA, with ammunition to oppose the truce. A day after the Church's communiqué, he distanced himself forcefully from the truce, condemning the government's treatment of the gangs and its failure to protect innocent citizens from

had proposed focusing on the local level. What was new and highly contested about the 'municipalities free from violence initiative' was the proposal to include gang members in the decision making and implementation of the programmes.

${ }^{97}$ Tregua es una negociación hipócrita: fiscal general', La Prensa Gráfica, 18 April 2013, p. 20.

${ }^{98}$ 'Fiscal Martínez reitera críticas contra tregua entre pandillas', La Prensa Gráfica, 19 April 2013, p. 10; 'Fiscal: “Tregua de pandillas es falsa e hipócrita", El Diario de Hoy, 9 May 2013, p. 10.

${ }^{99}$ Iglesia se distancia de la tregua entre pandillas', El Diario de Hoy, 13 May 2013, pp. 3-5. 
gang-related violence and delinquency. ${ }^{100}$ By the end of the same month, ARENA had distanced itself formally from the truce and rejected it as 'un acuerdo oscuro' ('a shady deal'). It proclaimed that the biggest beneficiaries were the gangs themselves, not society. ${ }^{101}$ Within days, two other presidential candidates, from FMLN and the Gran Alianza por la Unidad Nacional (Grand Alliance for National Unity, GANA), also publicly distanced themselves from the truce. ${ }^{102}$ In a very short period of time a range of social, religious and political actors in Salvadorean society had turned against the truce.

It is interesting to note that criticism of the truce was not orchestrated by a platform or movement, but arose as a discursive coalition of rejection. The opposition frames focused on the lack of legitimacy of the truce, which had always been a vulnerable aspect of the pro-truce frames. Moreover, the effectiveness frame had lost some of its traction, since there was increasing criticism of ongoing extortion and suspected gang involvement in disappearances. Much to the frustration of the supporters of the truce, it proved hard to stem this criticism. The secretary general of the OAS (a supporter of the truce) complained about the extremely critical voices that were happy to use increases in homicide rates as proof of the failure of the truce. ${ }^{103}$

Changes in support for the truce coincided with the appointment of a new minister of JPS. On 17 May 2013, a ruling of the Constitutional Court declared unconstitutional the appointments of former General Munguía Payés as minister of JPS and former General Salinas as director of the PNC, because they violated the separation of national defence from public security, and the independence of the PNC from the armed forces. ${ }^{104}$ With the appointment of Ricardo Perdomo as replacement on 29 May, the already limited government backing for the truce dwindled rapidly. From his first day in office the new minister distanced himself openly from the truce process and, even more importantly, cancelled a major part of the practical and logistical support provided by his ministry. ${ }^{105}$ Perdomo argued that the government had to take the lead in the process of violence reduction, and was not willing to cooperate with gang leaders, only with leaders who had left the gangs. ${ }^{106} \mathrm{He}$ also prohibited press access to imprisoned gang members and the periodic meetings between rival gang leaders in prison and their contacts

\footnotetext{
${ }^{100 ‘}$ Quijano critica trato del Gobierno a las pandillas', El Diario de Hoy, 14 May 2013, p. 14. It should be stressed that there had been discussions in ARENA's campaign team about electoral strategy regarding the truce. After the CEDES declaration it was decided to reject the truce and to support a more repressive strategy.

${ }^{101}$ Rafael Mendoza López, 'ARENA: Funes ha fracasado en seguridad', Noticias de El Salvador, 30 May 2013, https://www.elsalvador.com/noticias/nacional/106965/arena-funes-ha-fracasado-en-seguridad/.

${ }^{102 ،}$ Candidatos retiran apoyo a tregua entre las pandillas', El Diario de Hoy, 8 June 2013, pp. 8-10.

${ }^{103}$ Valencia, 'Obituario de la Tregua'.

${ }^{104}$ Corte Suprema de Justicia de El Salvador, Sentencia 04-2012, 17 May 2013, https://sv.vlex.com/vid/440530146. See also Jessica Ávalos, Jessel Santos and Cristian Meléndez, 'Sala CSJ ordena salida militares de Seguridad Pública', La Prensa Gráfica, 18 May 2013, pp. 2-3.

${ }^{105 ‘}$ Nuevo Ministro de Seguridad desliga a Gobierno de tregua', La Prensa Gráfica, 30 May 2013, pp. 246; 'Perdomo se desmarca de la tregua de pandillas', El Diario de Hoy, 30 May 2013, p. 20; 'Perdomo: No sabíamos que los reos saldrían a entrevista de televisión', El Diario de Hoy, 31 May 2013, pp. 2-3.

${ }^{106}$ Carlos Martínez and José Luis Sanz, 'Gobierno desmantela la tregua y los homicidios alcanzan 30 en un día', El Faro, 24 May 2014, http://www.salanegra.elfaro.net/es/201405/cronicas/15432/Gobierno-desmantela-la-tregua-y-los-homicidios-alcanzan-30-en-un-d\%C3\%ADa.htm.
} 
with the two facilitators. ${ }^{107}$ By revoking practical and logistical support for the truce, Perdomo - over the space of just a couple of weeks - dismantled the infrastructure that had enabled communication between gangs and government, ${ }^{108}$ thereby withdrawing the de facto support that the Salvadorean government had provided to the historical leaders in the prisons and seriously hampering the capacity of imprisoned gang leaders to communicate with their members outside the prisons. While the truce was not dead at this point, it is fair to say that keeping it proved more and more difficult.

A second backlash came when Public Prosecutor Martínez announced that he would start a series of investigations into the involvement of government officials, among them the former facilitator Raúl Mijango. ${ }^{109}$ Over the course of 2013, people who had cooperated with the truce process, at both national and local level, started to fear criminal persecution. Public Prosecutor Martínez targeted the remaining organisational structures of the truce process. In May 2014, a number of gang representatives who were involved in the truce process and had cooperated with Mijango were arrested. On that occasion Martínez made it clear that the fact that their role in the truce process was facilitated by the government was of no importance to him: 'when I detain someone I am not going to ask whether they are being protected by this or that facilitator. ${ }^{110}$ Martínez repeatedly called gang members 'terrorists' and initiated anti-terrorism legislation against them. ${ }^{11} \mathrm{He}$ added that the mediators of the truce were 'farsantes' ('phoneys'), and challenged Adam Blackwell, Secretary for Multidimensional Security of the OAS and 'guarantor of the agreements' (garante de los acuerdos), to finally recognise this. ${ }^{112}$ Thus, the prosecutor was not simply taking measures to investigate the legality of the truce, but had become deeply involved in the struggle to discredit the legitimacy of what he argued to be nothing more than a farce.

The arrests of gang members working with Mijango eventually led to the disbanding of the team that he had formed to manage the truce. ${ }^{113}$ A number of members decided to quit, fearing arrest. ${ }^{114}$ Mijango explained that they had lost their belief in the process: '[They said] they had better go the United States, because

${ }^{107}$ Ibid.
${ }^{108}$ Ibid.
${ }^{109}$ FGR confirma que investiga nueva tregua entre pandillas', La Prensa Gráfica, 10 Aug. 2015, p. 10; 'Fiscalía investiga a diez funcionarios por tregua', El Mundo, 12 Aug. 2015, https://elmundo.sv/fiscaliainvestiga-a-diez-funcionarios-por-tregua/. Munguía Payés and Mijango testified in June 2014 in the office of the chief public prosecutor in Santa Elena. See Nelson Rauda Zablah, 'Fiscal promete "investigación seria” de la tregua y pide declaración del expresidente Funes', El Faro, 2 Feb. 2016, http://www.elfaro. net/es/201602/el_salvador/17954/Fiscal-promete-investigación-seria-de-la-tregua-y-pide-declaración-delexpresidente-Funes.htm.

${ }^{110}$ Martínez and Sanz, 'Gobierno desmantela la tregua'.

${ }^{111}$ 'Fiscal: Juzgaremos como terroristas a atacantes de policías y soldados', El Diario de Hoy, 16 April 2014, p. 6.

${ }^{112}$ 'Viernes es el más violento del año con 31 asesinatos', La Prensa Gráfica, 14 May 2014, pp. 6-7.

${ }^{113}$ Martínez and Sanz refer to anonymous government officials who suggest that these leaders were arrested with a view to discrediting this remaining dialogue mechanism: 'Gobierno desmantela la tregua'. Mijango recognised that the arrest had made his work almost impossible. CvdB interview with Raúl Mijango, 9 Feb. 2015, San Salvador.

${ }^{114}$ Martínez and Sanz, 'Gobierno desmantela la tregua'. 
in El Salvador there [were] no possibilities for personal development. They left the gang, wanted to contribute to the solution, but the government [didn't] provide any space [for this]. ${ }^{115}$ Moreover, the context in which they had to do their work had become much more difficult: ${ }^{116}$ the OAS and the EU had had to scale back their involvement in the truce, since the national government was their formal counterpart. EU funding for the FH was stopped, ${ }^{117}$ and the role of the OAS reduced. Although the facilitators tried to continue the process, both at the national level and in a number of municipalities where local violence-reduction measures had been started, the dismantling of the national 'infrastructure' that had made the truce work and the emergence of an influential counter-frame led to a further unravelling of the process. The new president, Sánchez Cerén (FMLN), who took office on 1 June 2014, rejected the truce. Although Mijango still alleged in April 2014 that the truce was alive, ${ }^{118}$ by October 2015 he was convinced that it had died in June 2013. ${ }^{119}$

\section{Conclusion}

The Salvadorean gang truce was a unique and complex political process in which the rules in the FSG were challenged, temporarily changed and restored. The political space for a truce was and remained extremely limited in the Salvadorean context and in that regard it is quite surprising that the truce emerged in the first place. Several factors can shed light on why and how this happened. Firstly, the context of extremely high homicide rates and the failure of zero-tolerance policies to reduce them demanded innovative and unconventional measures that went beyond 'more repression'. Secondly, the willingness of the new minister of JPS, Munguía Payés (supported by the president of the republic), and the Salvadorean government to sponsor the truce and to actively support a hybrid security arrangement, in which street gangs promised to contain violence, facilitated that process, e.g. by transferring gang leaders to ordinary prisons and relaxing the prison regime. Thirdly, the minister outsourced the task of dealing with gangs to facilitators who were able to broker the deal between a number of imprisoned historical gang leaders and to keep the truce going. Finally - and crucially - all this was done backstage.

Even more surprising than the fact that a truce emerged was that it survived when its existence was revealed. The officials who had started the initiative still supported it, but this could not compensate for fragile political will and reluctance to 'formalise' the truce. The facilitators took the lead, obtained the support of part of the Catholic Church and connected with a number of national civil society representatives and NGOs, as well as with international organisations such as the EU

\footnotetext{
${ }^{115}$ CvdB interview with Raúl Mijango, 9 Feb. 2015, San Salvador.

${ }^{116}$ Ibid.

${ }^{117} \mathrm{Ibid}$. Other funds were secured.

${ }^{118}$ Carlos Martínez, 'Funes da por rota la tregua y Mijango lo descalifica', El Faro, 28 April 2014, http:// www.elfaro.net/es/201404/noticias/15313/.

${ }^{119}$ Roberto Valencia and Carlos Martínez, 'Hoy toca que los sedientos de sangre, los de las pandillas y los del gobierno, se sacien', El Faro, 12 Oct. 2015, http://www.salanegra.elfaro.net/es/201510/entrevistas/17432/ \%93Hoy-toca-que-los-sedientos-de-sangre-los-de-las-pandillas-y-los-del-gobierno-se-sacien\%94.htm.
} 
and OAS. Thus the truce increasingly became a process supported by a new coalition of actors that developed its own view on the gang phenomenon as well as innovative practices to deal with gangs. The legitimising frames of these actors mostly pointed at the effectiveness of the truce in terms of the reduction in homicide rates. These claims led to - mostly passive - support and endorsement by the leaders of the main political parties. This new approach to threat management challenged the rules in the FSG by giving the gangs a role in violence reduction. It temporarily changed practices by introducing various new instruments, including encouraging dialogue between gangs themselves and with the government through facilitators, outsourcing tasks with a view to achieving a substantial reduction in violence, and involving gangs actively in local programmes that aimed for a sustainable solution to the gang problem. These efforts were defended and supported by a relatively small 'pro-truce' coalition.

The truce had been criticised from the outset, but the resistance increased at the moment when the initiative was expanded to the local level. Actors such as the judicial sector, the Catholic Church and political parties were key in the process of resisting the truce initiative. The effort to reverse the truce was not the result of an organised campaign, but rather a process in which, over just a couple of months, a range of actors changed their opinion and position and probably also influenced each other in this process. The frames of the pro-truce coalition were challenged, partly by questioning the effectiveness of the truce, but predominantly by pointing to the illegal and allegedly criminal character of the truce. On the other hand, the change of the minister of JPS was of crucial importance in the demolition of the very infrastructure that allowed facilitators to stay in touch with the imprisoned leaders. The prosecutions of gang leaders and 'supporters' of the truce by the public prosecutor contributed to the further unravelling of the truce and of a reinstatement of the rules in the FSG as they had existed before the truce. While the truce had challenged security management in the FSG, by June 2013 the efforts to change the practices in the FSG had been neutralised and the old rules of the game re-established.

While the Salvadorean gang truce was a unique process, the analytical framework used in this study is relevant for the analysis of the politics of security governance in other countries where non-state armed actors have built up strong positions of power, even if the rules in the FSG are not challenged as openly as in El Salvador. However, while the politics of violence reduction will be different in each case, several elements of the framework used in this study can bring to light the hidden dynamics of security governance. Firstly, the notion of security governance as a field where the definition of threats and the forms of threat management are at stake shows the changing and contested nature of security governance. The importance of these contestations should not be underestimated in places where violence is endemic and where there appears to be agreement about the existence of security threats (such as gangs) and the forms of threat management. It is precisely in these places that contestations about how to manage a threat can be more intense than in places where everything seems to be under control. In particular, proposals for and efforts at engaging in dialogue or cooperation with non-state armed actors - from rebel movements to illicit groups - that are (or were previously) considered enemies of the state are likely to lead to high levels of contestation, since they challenge earlier understandings of threats and threat 
management. Secondly, a wide variety of actors is involved in the process of defining threats and debating what are adequate ways to manage them, and the positions of actors in these debates can shift. The case of the Salvadorean gang truce shows the involvement of a growing number of actors, whose agency changes, while more 'passive' audiences can turn into active actors taking issue with new or old security practices. It also shows that the support basis for these kinds of radical changes in security practices is not static. Thirdly, both formal and informal security practices matter, and it is important to tease out the relations between the two. Interestingly, the Salvadorean case shows how, initially, the formal repressive approach of the Salvadorean government was complemented with an informal effort to facilitate a deal with gangs. This raises questions about the ways in which informal and formal practices complement each other in other cases of security governance where the state is challenged by non-state actors. The range of informal practices is obviously broader than facilitation of a truce and can also include repression (extrajudicial killings) or liaisons with illicit groups. Fourthly, the relationship between discursive and non-discursive practices seems to be different for formal and informal practices. In formal security practices framing is an important part of the action. However, informal practices are usually carried out in silence, or are framed only for those actors involved, not for broader audiences. Although the duration of the truce, whilst garnering passive and active support, is quite impressive, it also demonstrates the enormous challenges entailed in 'formalising the informal': framing an informal security practice as a legitimate practice to broader audiences.

Acknowledgements. The authors would like to thank various persons interviewed for this research and the anonymous reviewers of this article for their comments. The paper also benefitted from feedback provided by participants of the conflict studies research seminar at Utrecht University.

\section{Spanish abstract}

Este artículo analiza la tregua entre las tres principales pandillas callejeras de El Salvador facilitada por el gobierno en 2012. A través de teorías de campo y de securitización, se mapea la evolución de la suspensión de hostilidades, haciendo distinción entre los tres procesos relacionados de hacer el pacto, mantener la tregua y desmantelarla. El artículo analiza los complejos e intrigantes procesos políticos en los que varios actores, como líderes pandilleros, funcionarios gubernamentales y organizaciones internacionales, interactuaron entre ellos y pactaron sobre el uso y visibilidad de la violencia y las maneras de disminuirla, evitarla o esconderla.

Spanish keywords: tregua pandillera; reducción de violencia; gobernanza de seguridad híbrida; política de tregua; campo de acción estratégica

\section{Portuguese abstract}

Este artigo analisa uma trégua firmada, com a ajuda do governo, entre as três principais gangues de El Salvador em 2012. Utilizando a teoria de campo e a teoria de securitização, o artigo mapeia a evolução do acordo, fazendo distinções entre os três processos correlatos de firmar o acordo, manter a trégua e desmantelá-la. O artigo analisa os complexos e intrigantes processos políticos em que diversos atores, tais como líderes de gangues, 
funcionários do governo e organizações internacionais, interagiram uns com os outros e fizeram acordos sobre o uso e a visibilidade da violência e as maneiras de diminuir, prevenir ou ocultá-la.

Portuguese keywords: trégua entre gangues; redução da violência; governança de segurança híbrida; política de tréguas; ação de campo estratégica

Cite this article: van der Borgh C, Savenije W (2019). The Politics of Violence Reduction: Making and Unmaking the Salvadorean Gang Truce. Journal of Latin American Studies 51, 905-928. https://doi.org/ $10.1017 /$ S0022216X19000890 